\title{
Presence of Alexandrium catenella and paralytic shellfish toxins in finfish, shellfish and rock crabs in Monterey Bay, California, USA
}

\author{
Rozalind J. Jester · Keri A. Baugh $\cdot$ Kathi A. Lefebvre
}

Received: 5 May 2008 / Accepted: 26 November 2008 / Published online: 7 January 2009

(C) The Author(s) 2009. This article is published with open access at Springerlink.com

\begin{abstract}
The central California coast is a highly productive, biodiverse region that is frequently affected by the toxin-producing dinoflagellate Alexandrium catenella. Despite the consistent presence of A. catenella along our coast, very little is known about the movement of its toxins through local marine food webs. In the present study, we investigated 13 species of commercial finfish and rock crabs harvested in Monterey Bay, California for the presence of paralytic shellfish toxins (PSTs) and compared them to the presence of $A$. catenella and PSTs in sentinel shellfish over a 3-year period. Between 2003 and 2005, A. catenella was noted in $55 \%$ of surface water samples $(n=307)$ and reached a maximum concentration of 17,387 cells $\mathrm{L}^{-1}$ at our nearshore site in Monterey Bay. Peak cell densities occurred in the month of July and were associated with elevated shellfish toxicity in the summers of 2004 and 2005. When A. catenella was present, particulate PSTs were detected $71 \%$ of the time and reached a maximum concentration of $962 \mathrm{ng}$ STXeq L ${ }^{-1}$. Of the 13 species tested, we frequently detected PSTs in Pacific sardines
\end{abstract}

Communicated by U.-G. Berninger.

Electronic supplementary material The online version of this article (doi:10.1007/s00227-008-1103-z) contains supplementary material, which is available to authorized users.

R. J. Jester ( $\square)$

Ocean Science Department, University of California, Santa Cruz, 1156 High St., Santa Cruz, CA 95064, USA e-mail: rjester@edison.edu; rozalind.jester@gmail.com

K. A. Baugh · K. A. Lefebvre

Marine Biotoxins Program, Environmental Conservation Division, Northwest Fisheries Science Center, NOAA-Fisheries,

2725 Montlake Blvd. East, Seattle, WA 98112, USA
(Sardinops sagax; maximum $250 \mu \mathrm{g}$ STXeq $100 \mathrm{~g}^{-1}$ ), northern anchovies (Engraulis mordax; maximum $23.2 \mu \mathrm{g}$ STXeq $100 \mathrm{~g}^{-1}$ ), brown rock crabs (Cancer antennarius; maximum $49.3 \mu \mathrm{g}$ STXeq $100 \mathrm{~g}^{-1}$ ) and red rock crabs (C. productus; $23.8 \mu \mathrm{g}$ STXeq $100 \mathrm{~g}^{-1}$ ). PSTs were also present in one sample of Pacific herring (Clupea pallas; $13.3 \mu \mathrm{g}$ STXeq $100 \mathrm{~g}^{-1}$ ) and one sample of English sole (Pleuronectes vetulus; $4.5 \mu \mathrm{g}$ STXeq $100 \mathrm{~g}^{-1}$ ), and not detected in seven other species of flatfish tested. The presence of PSTs in several of these organisms reveals that toxins produced by $A$. catenella are more prevalent in California food webs than previously thought and also indicates potential routes of toxin transfer to higher trophic levels.

\section{Introduction}

Paralytic shellfish toxins (PSTs) are produced by members of the dinoflagellate genus Alexandrium and consist of a suite of neurotoxins that are known to adversely affect human health and marine wildlife. Saxitoxin (STX) is the most potent of the PSTs. Human intoxication usually occurs through the consumption of PST-contaminated shellfish and results in a syndrome called paralytic shellfish poisoning (PSP) that can, in acute cases, lead to death. The seriousness of this problem was recognized in the 1920s after a PSP outbreak in California killed six people and sickened nearly a 100 more (Meyer et al. 1928; Sommer and Meyer 1937). This PSP event eventually led to the institution of extensive shellfish monitoring programs in the US and resulted in the establishment of a regulatory limit of $80 \mu \mathrm{g}$ STXeq $100 \mathrm{~g}^{-1}$ of shellfish, currently still in use (Price et al. 1991; Wekell et al. 2004).

Although shellfish appear to be the most serious vectors of PSTs to humans, the accumulation of these toxins 
in other filter-feeding organisms and the subsequent trophic transfer to higher-level predators is a global phenomenon that has resulted in severe mortality events involving finfish, marine mammals and seabirds (McKernan and Scheffer 1942; White 1977, 1980; Hortsman 1981; Geraci et al. 1989; Montoya et al. 1996; Pitcher and Calder 2000). Zooplankton and planktivorous fish are a primary vector of PSTs in many ecosystems, and, as with bivalves, can provide a direct link between the toxic cells and higher trophic levels (Teegarden and Cembella 1996; Pitcher and Calder 2000; Turner et al. 2000; Durbin et al. 2002; Doucette et al. 2005). Several reports indicate zooplankton and/or planktivorous fish serve as an important step in the transfer of PSTs involved in kills of Argentine mackerel (Mianzan et al. 1997), Atlantic herring (White 1977; 1980), Atlantic salmon (Sephton et al. 2007) and even humpback whales in the Gulf of Maine (Geraci et al. 1989). Although rare, human illnesses and fatalities have been directly attributed to the ingestion of PSTs contained in toxic planktivorous fish in Southeast Asia and Papua New Guinea, where it is customary to consume the entire fish (MacLean 1979; Halstead and Schantz 1984; Kao 1993). In addition to pelagic food webs, PSTs have also been detected in crabs and lobsters in the US, Canada, and Japan, providing evidence for toxin exposure to benthic communities (Oshima et al. 1984; Desbiens and Cembella 1997; Shumway 1995; Oikawa et al. 2002, 2007; Sephton et al. 2007). A thorough review of PSTs in marine organisms is given in Lansberg (2002).

Since the inception of the California biotoxin monitoring program [California Department of Public Health $(\mathrm{CDPH})]$, it has become clear that elevated levels of PSTs in shellfish occur on a nearly annual basis (Price et al. 1991; Horner et al. 1997). Interestingly, and unlike other regions frequently affected by PSP events, there is no evidence that PSTs have sickened or killed fish, mammals or birds in the monitored region. In fact, the extent to which these toxins are transferred through local food webs is virtually unknown. The most extensive food web survey of PSTs in this region, by Sommer and Meyer (1937), tested various invertebrates that co-occur in nature with mussels, including common species of barnacles, limpets, snails, chitons, sea stars, sea urchins, worms and sea anemones. Based on the toxin detection methods available at the time, the authors reported the possibility of trace levels of toxin in sea stars, limpets and chitons. However, they remained cautious about their results, suggesting that the analysis be repeated, and concluded that it was unlikely that "poison" levels (i.e. PSTs) in these other invertebrates would exceed that in mussels (Sommer and Meyer 1937). To date, the only organisms confirmed to regularly acquire PSTs in California are a variety of shellfish species and, at least periodically, the common sand crab (Emerita analoga) (Sommer 1932; Sommer and Meyer 1937; Price et al. 1991). Though not routinely monitored, Bretz et al. (2002) suggest that PST levels in sand crabs are comparable to those in adjacent mussel beds and could be a useful indicator species along sandy coastlines where shellfish are absent.

Although little is known about the transmission of PSTs through the food web in this region, the occurrence of another algal toxin, domoic acid (DA), can lend insight into potential routes of trophic transfer. Along the California coast, the transfer of DA through planktivorous fish, Pacific sardines (Sardinops sagax) and northern anchovies (Engraulis mordax), has been the cause of serious seabird and marine mammal mortalities (Fritz et al. 1992; Work et al. 1993; Lefebvre et al. 1999; Scholin et al. 2000). An increased interest in the movement of DA through the food web resulted from these events and DA has since been detected in several organisms, including benthic invertebrates, crabs, krill, squid, flatfish and even whale feces (Langlois et al. 1993; Bargu et al. 2002; Lefebvre et al. 2002a; Goldberg 2003; Vigilant and Silver 2007; Bargu et al. 2008). The presence of DA in these animals demonstrates that they are susceptible to the uptake of algal toxins. These findings, along with the knowledge that PSTs have been detected in many of these animals in other regions, e.g. zooplankton (Turner et al. 2000; Doucette et al. 2005), crabs (Shumway 1995), planktivorous fish (White 1977, 1980; Pitcher and Calder 2000) and whales (Geraci et al. 1989), suggests that PSTs may also be present in California food webs to a further degree than we are currently aware of.

Our intent in the present study was to investigate organisms that are potentially accumulating PSTs off the California coast, with the goal of gaining a better understanding of potential routes of trophic transfer. The coastal upwelling region of Monterey Bay is a highly productive area that supports a diversity of resident and migratory wildlife, as well as important commercial fisheries. Here, we present data collected over a 3-year period in Monterey Bay on the presence of PSTs in several species of commercially harvested finfish and rock crabs compared to the presence of A. catenella and PSTs. Among those fisheries we studied were those that harvest sardines and anchovies, operations whose combined landings in 2006 made up $43 \%$ of a $\$ 6.4$ million fishery in California (California Department of Fish and Game Marine Region 2007). Given the efficiency with which these planktivorous fish vector algal toxins to higher trophic levels, it follows that they can pose a potentially serious threat to secondary consumers in the presence of local toxin-producing cells. 


\section{Materials and methods}

Phytoplankton sampling and identification

From January 2003 to December 2005, weekly surface water samples were collected using a bucket at two sites within Monterey Bay, California (Fig. 1): nearshore at the Santa Cruz wharf (SCW; 36.95 N, 122.02 W) and offshore at the Monterey Bay Aquarium Research Institute's M1 mooring $(36.75 \mathrm{~N}, 122.02 \mathrm{~W})$. SCW water samples were immediately transported to the lab for processing, while M1 samples were collected midday aboard the $R / V P t$. Lobos, stored in a dark cooler, and transported to the lab for processing approximately $6 \mathrm{~h}$ after collection. Upon arrival, a $10-100 \mathrm{ml}$ subsample of well-mixed surface water was filtered and preserved for identification and enumeration of A. catenella using whole-cell oligonucleotide probes according to Miller and Scholin (1998, 2000) and Scholin et al. (1994). The probe (NA-1) used in this study has been shown to cross react with $A$. tamarense and $A$. fundyense (Scholin 1994). We use the designation of $A$. catenella throughout the paper because the cross reacting species are not known to occur along the California coast and fluorescent microscopy, indicated the frequent presence of chains, also supportive of the A. catenella designation (Balech 1995). To determine the concentration of particulate PSTs, an additional $1 \mathrm{~L}$ surface water sample was collected, filtered on $47 \mathrm{~mm}, 0.45 \mu \mathrm{m}$ nitrocellulose filters (Millipore

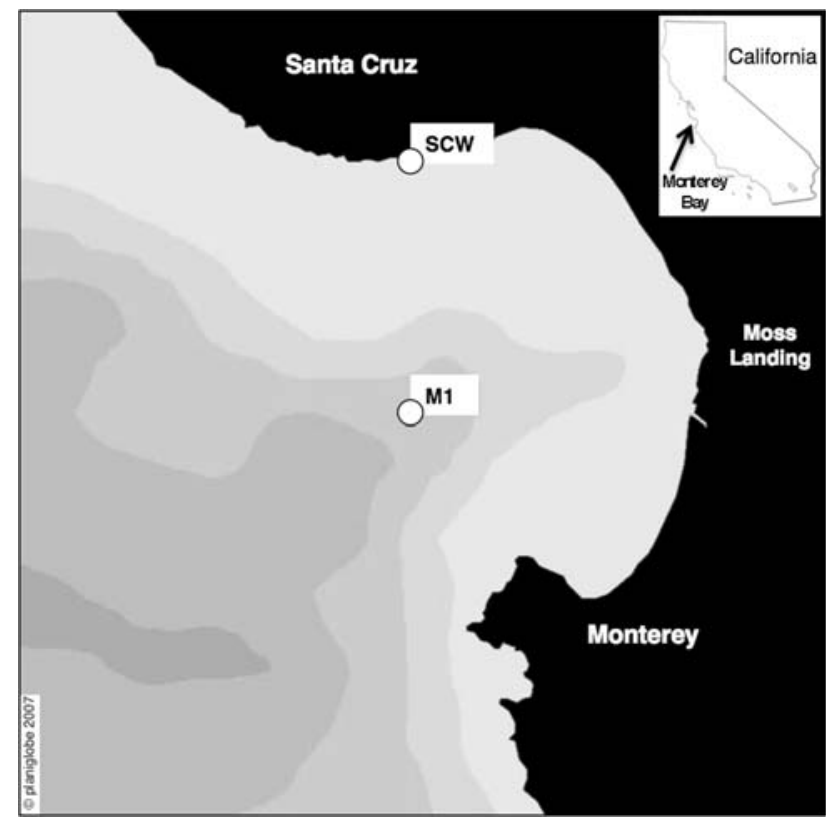

Fig. 1 Two sample sites in Monterey Bay, California, where weekly surface water samples were collected for A. catenella counts and particulate paralytic shellfish toxin (PST) measurements: nearshore at the Santa Cruz wharf (SCW) and offshore at the Monterey Bay Aquarium Research Institute's M1 mooring
Corp., Bedford, MA, USA), and the filters stored at $-20^{\circ} \mathrm{C}$ until extraction. One to three filters were used for each $1 \mathrm{~L}$ sample depending on the density of particulate matter present in the seawater. The term "particulate PSTs" refers to toxin levels contained within the phytoplankton cells sampled and does not include potential extracellular toxins that may be released into the water column.

Fish, crab and mussel collection

Throughout the A. catenella sampling period, we opportunistically collected planktivorous fish, benthic-dwelling flatfish, and rock crabs to analyze for PSTs. Planktivorous fish, including northern anchovies (E. mordax), Pacific sardines (S. sagax) and Pacific herring (Clupea pallasii), were caught within Monterey Bay by local commercial fishermen between January 2003 and December 2005. Freshly caught fish were collected dockside at either Moss Landing or Santa Cruz harbor, packaged whole and promptly placed in $\mathrm{a}-20^{\circ} \mathrm{C}$ freezer until processing. In preparation for toxin analysis, slightly thawed fish were dissected and the viscera of multiple specimens from each species removed, pooled and homogenized to provide one representative sample per species per sampling day. The total number of days sampled was 21 for sardines, 21 for anchovies and 3 for herring. The species and quantity of fish varied based on the day's catch and ranged from 8 to 90 individuals for anchovies, 4-34 individuals for sardines and 3-25 individuals for herring (S1). Aliquots of homogenized viscera were placed in $50 \mathrm{ml}$ conical tubes and frozen for later toxin analysis. A brief summary of these data was presented in Jester et al. (2008a).

In addition to planktivorous fish, we also analyzed viscera samples from bottom-dwelling flatfish collected during a co-occurring study of DA accumulation in benthic fish; sampling and processing details are described in Vigilant and Silver (2007). Monthly flatfish samples collected in or just outside of Monterey Bay between January and October 2003 included eight species: curlfin turbot (Pleuronicthys decurrens), Dover sole (Microstomus pacificus), English sole (Pleuronectes vetulus), Pacific sanddab (Citharichthys sordidus), petrale sole (Eopsetta jordani), rex sole (Errex zachirus), sand sole (Psettichthys melanostictus) and slender sole (Eopsetta exilis). Note that not all species were caught every month.

Between September 2004 and August 2005, brown rock crabs (Cancer antennarius) and red rock crabs (C. produc$t u s$ ) were periodically trapped at SCW (ca. 8-10 m depth) by lowering baited cages to the seafloor. A total of 19 dates were sampled for red rock crabs and 10 for brown rock crabs, and on most occasions only a single crab was captured (S1). Whole crabs were frozen upon collection and maintained at $-20^{\circ} \mathrm{C}$ until dissection. The hepatopancreas 
of all specimens of each species collected on the same day were removed, pooled by species (if $n>1$ ) and thoroughly homogenized prior to toxin analysis.

Mussels (Mytilus californianus) were chosen as a sentinel shellfish species and were collected weekly for comparison with A. catenella densities and PST levels detected in water samples, fish and crabs. Since our nearshore site, $\mathrm{SCW}$, is not in close proximity to accessible shellfish beds, mussels were harvested from a rocky intertidal beach north of Santa Cruz (Davenport Landing; 37.02 N, 122.21 W), placed in mesh bags (ca. 30 mussels) and suspended from the wharf a minimum of 7 days before collection. Each week, the contents of one mesh bag of SCW mussels were shucked, homogenized using a standard kitchen blender, frozen at $-20^{\circ} \mathrm{C}$ and shipped to the $\mathrm{CDPH}$ where they were analyzed for the presence of PSTs by the standard mouse bioassay (as described in AOAC 2000). These shellfish data are available online in the form of monthly reports at the CDPH biotoxin monitoring program website: http:// www.cdph.ca.gov/healthinfo/environhealth/water/Pages/ Shellfish.aspx. Because all other animal tissues were measured via receptor-binding assay (see below), a more sensitive method than the mouse bioassay, the toxin concentrations in mussels should not be directly compared to those we report in fish and crabs. Mouse bioassay results can, however, be used to indicate the general presence of PSTs in the food web and the magnitude of toxicity.

Toxin detection in phytoplankton and animal tissues

To extract PSTs from filtered seawater samples, $3.0-5.0 \mathrm{ml}$ of $0.1 \mathrm{M}$ glacial acetic acid were added to frozen, macerated filters. After the addition of extraction solvent, samples were sonicated on ice for $2 \mathrm{~min}$ and then centrifuged at $4000 \times g$ for $10 \mathrm{~min}$. The resulting supernatant was stored in a sealed vial at $-20^{\circ} \mathrm{C}$ until analysis.

Paralytic shellfish toxins were extracted from fish viscera and crab hepatopancreas within 4 weeks prior to analysis following the AOAC (2000) protocol used for analyzing shellfish. Equal volumes of extraction solvent $(0.1 \mathrm{~N} \mathrm{HCl})$ to sample weight (usually $10.0 \mathrm{~g}$ ) were well mixed, $\mathrm{pH}$ adjusted to $3 \pm 0.5$ and boiled for $5 \mathrm{~min}$. If necessary, samples were $\mathrm{pH}$ adjusted again and then centrifuged for $15 \mathrm{~min}$ at $4000 \times g$. The resulting supernatant was passed through a $0.45 \mu \mathrm{m}$ mixed cellulose ester syringe filter (Millipore Corp., Bedford, MA, USA) and frozen at $-20^{\circ} \mathrm{C}$ until analysis.

The concentration of PSTs was determined using a receptor-binding assay described in Trainer and Poli (2000). In this assay, scintillation spectroscopy was used to quantify the competitive displacement of toxin in the sample by $\left[{ }^{3} \mathrm{H}\right]$ saxitoxin (STX; Amersham, Buckinghamshire, England) bound to sodium channel receptors (prepared from rat brains; Pel-Freez Biologicals, Rogers, AR, USA). The concentration of toxin in the sample was determined by comparing the membrane-bound radioactivity to standard curves, which were generated for each assay run using a certified STX standard (National Research Council of Canada, Institute for Marine Biosciences, Halifax, Nova Scotia, Canada). Because this assay does not distinguish between different PST analogues, but rather determines the biological toxicity of the sample relative to that of the standard, the resulting concentrations are given in STX equivalents (STXeq). The lower limit of detection was determined to be $4.4 \mu \mathrm{g}$ STXeq $100 \mathrm{~g}^{-1}$ for animal tissues and $3.0 \mathrm{ng} \mathrm{L}^{-1}$ for water samples. Spike and recovery experiments were carried out in triplicate for sardine viscera and crab hepatopancreas and resulted in means of $83.6 \pm 5.3$ and $87.4 \pm 23.8 \%$ for each matrix type, respectively.

\section{Results}

Presence of A. catenella and particulate PSTs

Over the 3-year study period in Monterey Bay, the density of A. catenella ranged from not detected to a maximum of 17,387 cells $\mathrm{L}^{-1}$ nearshore at $\mathrm{SCW}$ and 16,707 cells $\mathrm{L}^{-1}$ offshore at M1 (Fig. 2). During this time, A. catenella was detected in $55 \%(n=307)$ of surface water samples and was observed throughout the year (Table 1). Although cells were routinely present, $82 \%$ of the time they were detected at low cell densities $\left(<1,000\right.$ cells $\left.L^{-1}\right)$. In 2003, peak abundances were observed in the fall (October) and were concentrated nearshore (SCW), in contrast to 2004 and 2005 when the highest densities occurred in the summer (June, July) and were present at both SCW and M1 (Fig. 2). In general, A. catenella exceeded 1,000 cells $\mathrm{L}^{-1}$ more frequently at $\mathrm{SCW}$, and in most cases, 1-2 weeks prior to reaching comparable levels at M1.

Particulate PSTs were also detected in more than half of the samples $(51 \%, n=221)$ analyzed for both cells and toxin (Fig. 2). In 1/5 of the samples A. catenella was present, yet no particulate toxins were detected; all of these, however, were $<1,000$ cells $\mathrm{L}^{-1}$ and all but five $<100$ cells $\mathrm{L}^{-1}$. There were ten occasions when PSTs were measured in the particulate fraction, when cells were not detected in the water column. The low range of particulate toxin in these ten samples (3.2-14.0 ng STXeq $\mathrm{L}^{-1}$ ) implies that cell densities were also low and likely below our level of detection (100 ml analyzed for cell counts and 1,000 ml for particulate PSTs). The maximum particulate toxin concentration measured during the study interval was $962 \mathrm{ng}$ STXeq $\mathrm{L}^{-1}$ at M1 and corresponded with the maximum cell abundance at that site (Fig. 2). Interestingly, the highest concentration at SCW was significantly lower, 
Fig. 2 A. catenella cell densities and particulate paralytic shellfish toxin (PST) concentrations over 3 years at SCW and M1 in Monterey Bay, California

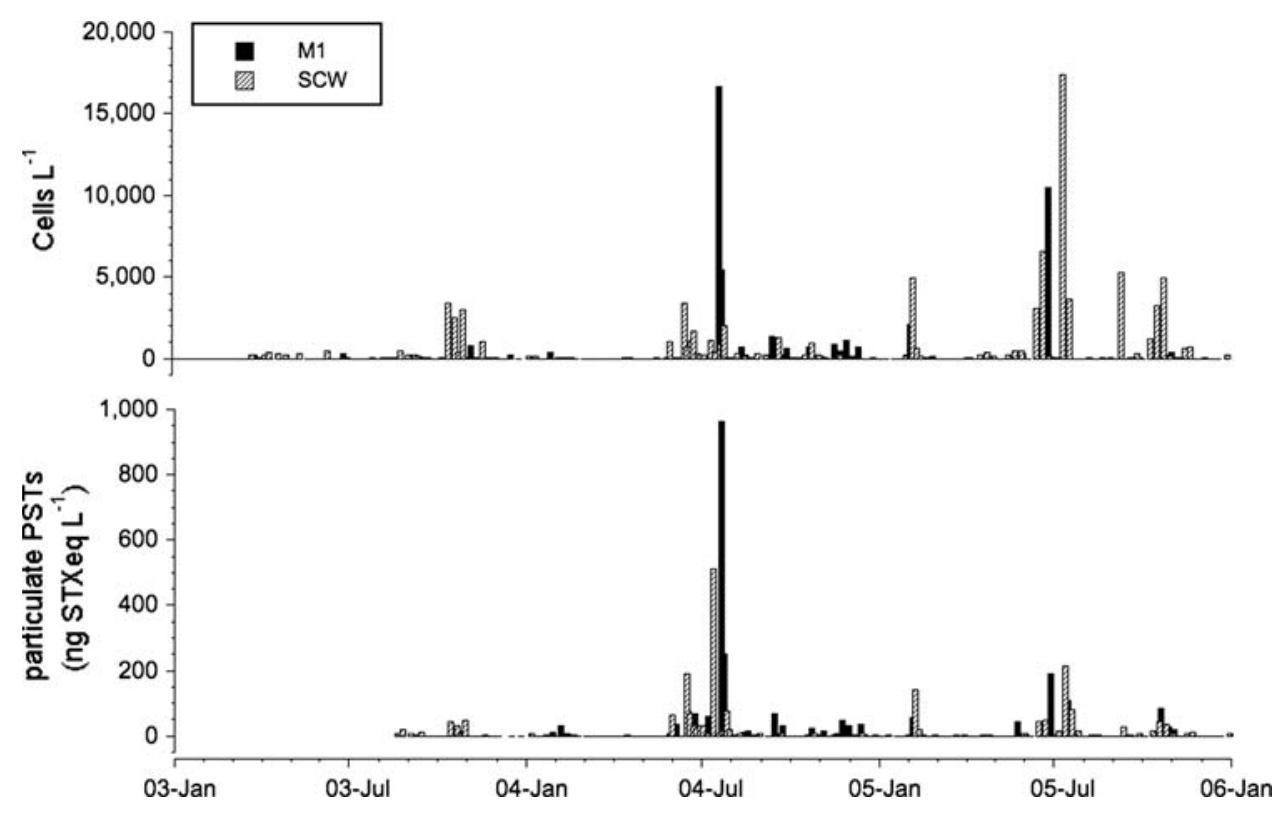

Table 1 Sample distribution of A. catenella cell densities by month in Monterey Bay, California between January 2003 and December 2005

\begin{tabular}{|c|c|c|c|c|c|c|}
\hline Month & Not detected & $<1,000$ cells $\mathrm{L}^{-1}$ & $1,000-4,999$ cells $\mathrm{L}^{-1}$ & $5,000-10,000$ cells $\mathrm{L}^{-1}$ & $>10,000$ cells $\mathrm{L}^{-1}$ & Total \\
\hline January & 15 & 6 & 0 & 0 & 0 & 21 \\
\hline February & 13 & 10 & 2 & 0 & 0 & 25 \\
\hline March & 20 & 4 & 0 & 0 & 0 & 24 \\
\hline April & 15 & 12 & 0 & 0 & 0 & 27 \\
\hline May & 14 & 10 & 0 & 0 & 0 & 24 \\
\hline June & 9 & 11 & 6 & 1 & 1 & 28 \\
\hline July & 17 & 11 & 5 & 1 & 2 & 36 \\
\hline August & 10 & 18 & 0 & 0 & 0 & 28 \\
\hline September & 4 & 15 & 2 & 1 & 0 & 22 \\
\hline October & 4 & 14 & 7 & 0 & 0 & 25 \\
\hline November & 5 & 18 & 1 & 0 & 0 & 23 \\
\hline December & 11 & 11 & 1 & 0 & 0 & 23 \\
\hline Total & 137 & 140 & 24 & 3 & 3 & 307 \\
\hline
\end{tabular}

$511 \mathrm{ng}$ STXeq $\mathrm{L}^{-1}$, and occurred at only a moderate cell density, 1,150 cells $\mathrm{L}^{-1}$. Unlike the highest cell densities at M1 and SCW, which occurred in consecutive summers, the highest particulate toxin concentrations at the two sites occurred in consecutive weeks in the summer of 2004. Linear regressions examining the relationship between A. catenella and particulate PSTs at SCW and M1, both show a significant positive correlation between cell abundance and toxin levels (SCW: $n=137, r=0.49$, $P<0.01$; M1: $n=84, r=0.93, P<0.01)$. The results of these regressions suggest that offshore cells are producing more toxins per cell on average than those at SCW. However, caution needs to be taken in the interpretation of this data due to the potential presence of PST containing zooplankton in our samples.
PSTs in the food web

\section{Sentinel mussels}

Paralytic shellfish toxins were detected by mouse bioassay in 50 of 126 mussel samples collected at SCW between 2003 and 2005. Of those samples, seven exceeded the regulatory limit of $80 \mu \mathrm{g}$ STXeq $100 \mathrm{~g}^{-1}$ and occurred during two discrete events in the summers of 2004 and 2005. An examination of the weeks preceding these samples shows that toxin was detected in mussels, a minimum of two consecutive weeks prior to exceeding the regulatory limit and that cell densities over 1,000 cells $\mathrm{L}^{-1}$ were detected at least once during that time (Table 2 ). The A. catenella densities that correspond with these samples also indicate that elevated 
Table 2 Dates when paralytic shellfish toxins (PSTs) in sentinel shellfish exceeded the regulatory limit (RL) as measured by mouse bioassay and the corresponding A. catenella cell densities and particulate toxin concentrations at Santa Cruz Wharf (SCW)

\begin{tabular}{|c|c|c|c|c|c|c|}
\hline \multirow{2}{*}{$\begin{array}{l}\text { Date mussels } \\
\text { exceeded RL } \\
(\mathrm{mm} / \mathrm{dd} / \mathrm{yy})\end{array}$} & \multirow{2}{*}{$\begin{array}{l}\text { PSTs in } \\
\text { mussels } \\
\left(\mu \mathrm{g} \text { STXeq } 100 \mathrm{~g}^{-1}\right)\end{array}$} & \multirow{2}{*}{$\begin{array}{l}\text { A. catenella } \\
\text { at } \mathrm{SCW} \\
(\text { cells L } \\
-1)\end{array}$} & \multirow{2}{*}{$\begin{array}{l}\text { Particulate } \\
\text { PSTs } \\
\text { (ng STXeq L }{ }^{-1} \text { ) }\end{array}$} & \multicolumn{3}{|c|}{$\begin{array}{l}\text { Preceding A. catenella densities } \\
\left({\left.\text { cells } \mathrm{L}^{-1}\right) \text { and mussel toxicity }}^{\mathrm{a}}\right.\end{array}$} \\
\hline & & & & 1 week prior & 2 weeks prior & 3 weeks prior \\
\hline $06 / 30 / 04$ & 81 & $330^{\mathrm{b}}$ & 30.3 & $1,050(+)$ & $3,400(+)$ & 90 (n.s.) \\
\hline 07/07/04 & 86 & $200^{\mathrm{b}}$ & 6.8 & $330(++)$ & $1,050(+)$ & $3,400(+)$ \\
\hline $07 / 14 / 04$ & 141 & $1150^{\mathrm{b}}$ & 511.8 & $200(++)$ & $330(++)$ & $1,050(+)$ \\
\hline $07 / 28 / 04$ & 770 & $2040^{\mathrm{b}}$ & 77.6 & $0(+)^{\mathrm{c}}$ & $1,150(++)$ & $200(++)$ \\
\hline 08/04/04 & 367 & $50^{\mathrm{b}}$ & 3.1 & $2,040(++)$ & $0(+)^{\mathrm{c}}$ & $1,150(++)$ \\
\hline $07 / 06 / 05$ & 165 & 40 & 14.4 & $110(+)$ & $6,550(+)$ & $3,100(+)$ \\
\hline $07 / 20 / 05$ & 232 & 3,670 & 80.9 & 17,387 (n.s.) & $40(++)$ & $110(+)$ \\
\hline
\end{tabular}

${ }^{a}$ Values in parentheses indicate level of mussel toxicity ( $+=$ toxin present but below RL, $++=$ exceeds RL, n.s. $=$ no sample)

b Water sample collected 1 day before mussel sample

${ }^{c}$ No A. catenella detected 1 or 2 weeks prior on 07/20/04, though extra samples collected that week indicate a sharp increase in cells, 880 cells $\mathrm{L}^{-1}$ on $07 / 23 / 04$ and 1,870 cells $\mathrm{L}^{-1}$ on $07 / 25 / 04$

toxin concentrations are not tightly coupled with high cell counts at the time of collection, and rather reflect an accumulation of toxins over a variable exposure period. For example, in both the summer of 2004 and 2005, A. catenella began to appear at high concentrations in June, coincident with a high proportion of "below regulatory limit" mussel samples, and then remained high through July, the month with the highest proportion of "above regulatory limit" mussels. Particulate toxin concentrations during these two events ranged from 6.8 to $511 \mathrm{ng}$ STXeq $\mathrm{L}^{-1}$ in 2004 and from 4.3 to $214 \mathrm{ng}$ STXeq $\mathrm{L}^{-1}$ in 2005 . The remaining 43 samples, that were positive for PSTs were below the regulatory limit and were distributed widely across seasons; in these 3 years, March was the only month in which PSTs were not detected.

Aside from the two prominent events in June-August 2004 and July 2005 when shellfish levels were above the regulatory limit, there were several other isolated events when mussels contained PSTs for multiple weeks, but remained below the regulatory limit. These occurred in April/May 2003, August 2003, October/November 2003, January 2004, October/November 2004, December 2004February 2005 and September/October 2005. All, but three, of these events can be attributed to persistent low cell counts $\left(<1,000\right.$ cells $\left.\mathrm{L}^{-1}\right)$ and low particulate PST levels. One exception occurred during the December 2004-February 2005 period, when after several weeks of low cell density, A. catenella reached 4,920 cells L ${ }^{-1}$ (140 ng STXeq $\mathrm{L}^{-1}$ ), yet mussels did not exceed the regulatory limit. The other exceptions occurred in October/November 2003 and September/October 2005 when A. catenella densities were elevated for three consecutive weeks (up to 3,380 and 5,270 cells $\mathrm{L}^{-1}$, respectively), but in this case, particulate PST concentrations never exceeded $46.5 \mathrm{ng}$ STXeq $\mathrm{L}^{-1}$. These results suggest that in order for mussels to exceed the regulatory limit they must, over a minimum period of 2-3 weeks, be exposed to high cell counts that are associated with moderate to high particulate PSTs concentrations.

\section{Planktivorous fish and flatfish}

Of the 11 fish species sampled in this study, PSTs were most commonly detected in the viscera of Pacific sardines and northern anchovies (Fig. 3). Toxins were present in 14 of 21 sardine samples ranging from 4.7 to $250 \mu \mathrm{g}$ STXeq $100 \mathrm{~g}^{-1}$ and in 10 of 21 anchovy samples ranging from 4.4 to $23.2 \mu \mathrm{g}$ STXeq $100 \mathrm{~g}^{-1}$. The maximum value in sardine viscera occurred on 23 July 2004, two days after A. catenella peaked at 16,707 cells $\mathrm{L}^{-1}$ (962 ng STXeq $\mathrm{L}^{-1}$ ) offshore at M1 (Fig. 2) and coincided with a period of positive shellfish toxicity at SCW (Fig. 3). The only positive herring sample $(n=3)$ was also collected on this date, but the concentration was much lower than in sardines, $13.3 \mu \mathrm{g}$ STXeq $100 \mathrm{~g}^{-1}$ (Table 3). The maximum level of PSTs in anchovies, $23.2 \mu \mathrm{g}$ STXeq $100 \mathrm{~g}^{-1}$, was observed 1 week later on 27 July 2004. The occurrence of PSTs in planktivorous fish is positively correlated $(n=46, r=0.46, P<0.01)$ with the presence of cells in Monterey Bay (average of M1 and $\mathrm{SCW}$ ), however the predictive relationship between cell numbers and viscera toxin concentrations is poor. This likely results from the fact that, like mussels, fish accumulate PSTs over a period of days to weeks and so the abundance of cells on or near the sampling date may not accurately reflect the preceding exposure period. Compounding that affect phytoplankton abundance is patchy by nature, so the cell densities at M1 and SCW may not be an accurate estimate of the feeding grounds of these wide-ranging fish.

There were six occasions when both anchovies and sardines were sampled on the same date (Table 3). Aside from 
Fig. 3 Paralytic shellfish toxins (PSTs) in the viscera of planktivorous fish caught within Monterey Bay, California between January 2003 and September 2005 compared to the presence of PSTs in sentinel mussels over the same time period

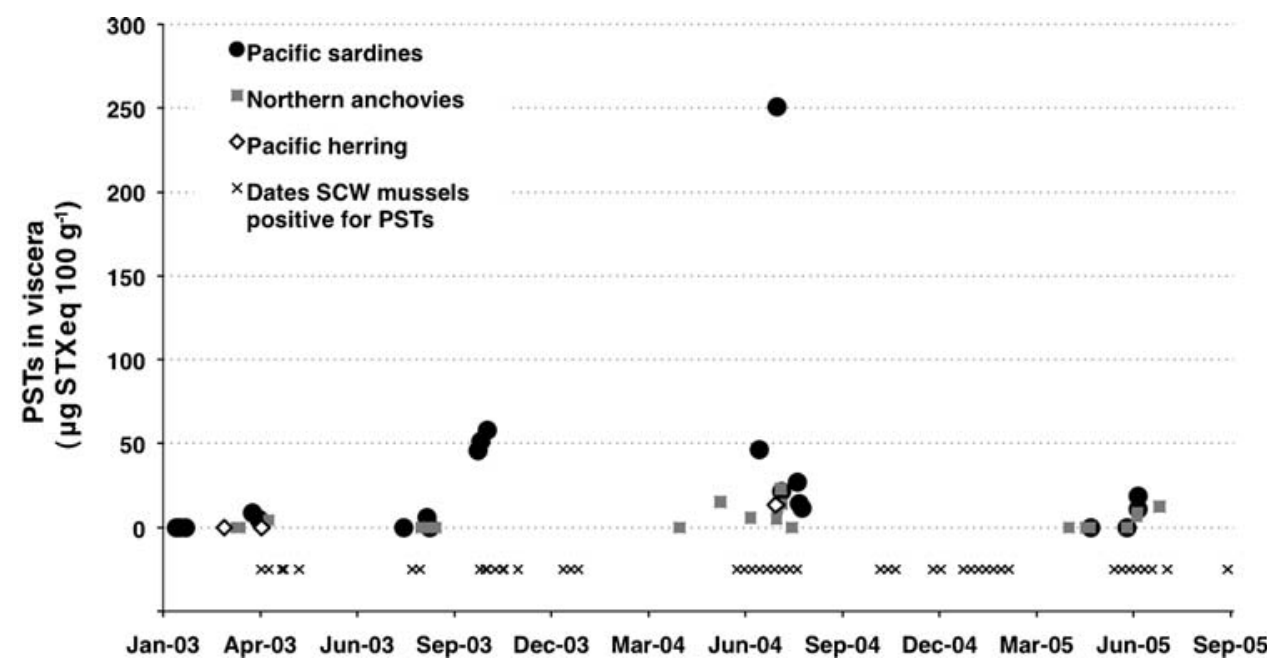

Table 3 Comparison of paralytic shellfish toxins (PSTs) in the viscera of northern anchovies, Pacific sardines and Pacific herring collected within Monterey Bay, California on the same date

\begin{tabular}{llll}
\hline $\begin{array}{l}\text { Date } \\
(\mathrm{mm} / \mathrm{dd} / \mathrm{yy})\end{array}$ & $\begin{array}{l}\text { Anchovy } \\
\text { viscera } \\
(\mu \mathrm{g} \mathrm{STXeq}\end{array}$ & $\begin{array}{l}\text { Sardine } \\
\text { viscera } \\
\left(\mu \mathrm{g} \mathrm{STXeq}^{-1}\right)\end{array}$ & $\begin{array}{l}\text { Herring } \\
\text { viscera } \\
(\mu \mathrm{g} \text { STXeq }\end{array}$ \\
\hline $07 / 23 / 04$ & 5.0 & 250.6 & $\left.130 \mathrm{~g}^{-1}\right)$ \\
$07 / 28 / 04$ & 13.8 & 21.4 & \\
$05 / 10 / 05$ & n.d. & n.d. & \\
$06 / 13 / 05$ & n.d. & n.d. & \\
$06 / 22 / 05$ & 7.0 & 10.8 & \\
$06 / 23 / 05$ & 8.9 & 18.5 & \\
\hline
\end{tabular}

n.d. not detected

the sample collected on 23 July 2004, when sardines had a much greater concentration of PSTs than anchovies, the differences in gut toxin levels between the two species are minimal. Unfortunately, the small sample size $(n \leq 7)$ does not permit an informative statistical comparison. There were no instances when toxin was detected in one species, but not the other.

One sample of English sole (10 Jun 2003) was positive for PSTs, though the concentration was very low, $4.5 \mu \mathrm{g}$ STXeq $100 \mathrm{~g}^{-1}$, and bordered our detection limit. The week of this sample, A. catenella was not detected at M1 and reached only 500 cells $\mathrm{L}^{-1}$ at SCW. Though a low cell count, we observed similar cell abundances that were associated with low levels of PSTs in sentinel shellfish. No toxin was detected in any other flatfish sample caught in $2003(n=61)$.

\section{Rock crabs}

Between September 2004 and August 2005, PSTs were detected in the hepatopancreas of both brown and red rock crabs (Fig. 4). A total of 13 brown rock crab $(n=19)$ and 6 red rock crab $(n=10)$ samples contained measurable PSTs that ranged from 4.5 to 49.3 and 4.5-23.8 $\mu$ g STXeq $100 \mathrm{~g}^{-1}$, respectively. The highest concentration in brown rock crabs, $49.3 \mu \mathrm{g}$ STXeq $100 \mathrm{~g}^{-1}$ (24 February 2005), occurred in a single crab that was collected during a period of persistent low density A. catenella at SCW and following two consecutive weeks of low toxicity sentinel mussels (below regulatory limit). The majority of red rock crab samples were either below the toxin detection limit or had very low concentrations. In contrast to brown rock crabs, PSTs were not detected in mussels nor were A. catenella cells present during the week of the maximum red rock crab concentration, $23.8 \mu \mathrm{g}$ STXeq $100 \mathrm{~g}^{-1}$ (4 August 2005). It is worth noting, however, that 2 weeks earlier, on 20 July 2005, the concentration in sentinel mussels peaked at $232 \mu \mathrm{g}$ STXeq $100 \mathrm{~g}^{-1}$, the highest level in SCW mussels that year.

On seven different dates, both brown and red rock crabs were collected (Table 4). Paralytic shellfish toxin concentrations were greatest in brown rock crabs on six of the seven occasions and as much as tenfold higher than that detected in a co-occurring red rock crab. This may suggest that brown rock crabs accumulate higher levels of PSTs than red rock crabs, although statistical significance is limited by the small sample size and further data are needed in order to substantiate this hypothesis. Nonetheless, these data demonstrate that both crab species are capable of acquiring PSTs and that these toxins are present in nearshore-benthic food webs.

\section{Discussion and conclusions}

The transfer of PSTs to higher trophic levels has been well documented in many regions of the world (for an extensive 
Fig. 4 Paralytic shellfish toxins (PSTs) in the hepatopancreas of rock crabs caught at Santa Cruz Wharf (SCW) between August 2004 and September 2005 compared to the presence of PSTs in sentinel mussels collected from SCW over the same time period

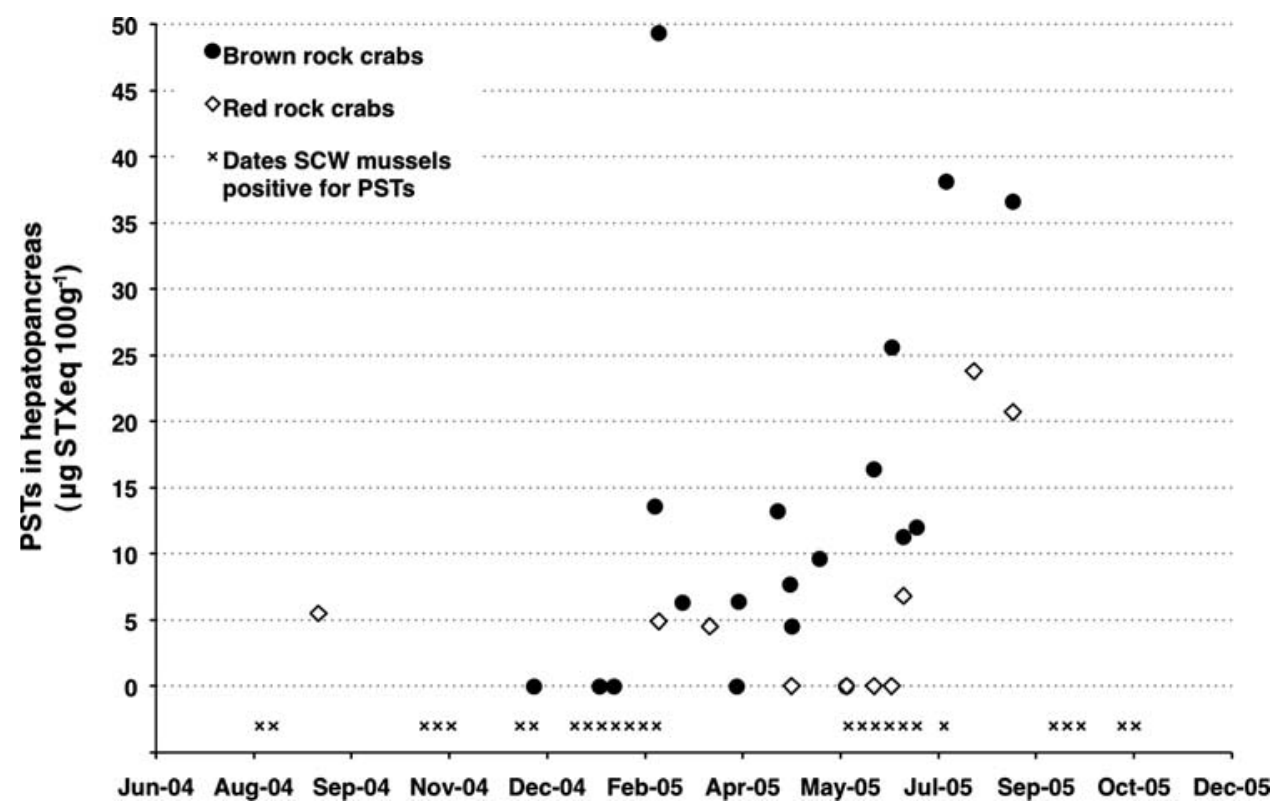

Table 4 Comparison of paralytic shellfish toxins (PSTs) in the hepatopancreas of brown and red rock crabs collected at Santa Cruz Warf (SCW) on the same date

\begin{tabular}{lll}
\hline $\begin{array}{l}\text { Date } \\
(\mathrm{mm} / \mathrm{dd} / \mathrm{yy})\end{array}$ & $\begin{array}{l}\text { Brown rock } \\
\text { crabs }(\mu \mathrm{g} \text { STXeq } \\
\left.100 \mathrm{~g}^{-1}\right)\end{array}$ & $\begin{array}{l}\text { Red rock } \\
\text { crabs }(\mu \mathrm{g} \text { STXeq } \\
\left.100 \mathrm{~g}^{-1}\right)\end{array}$ \\
\hline $02 / 24 / 05$ & 49.3 & 4.9 \\
$05 / 03 / 05$ & 4.5 & n.d. \\
$05 / 31 / 05$ & n.d. & n.d. \\
$06 / 14 / 05$ & 16.4 & n.d. \\
$06 / 23 / 05$ & 25.6 & n.d. \\
$06 / 29 / 05$ & 11.3 & 6.8 \\
$08 / 24 / 05$ & 36.6 & 20.7 \\
\hline
\end{tabular}

n.d. not detected

review see Lansberg 2002), but in California, there is virtually no knowledge of the pervasiveness of PSTs in the food web. In this region, the only organisms known to routinely accumulate these toxins are filter-feeding bivalves and the common sand crab, E. analoga (Sommer 1932; Sommer and Meyer 1937; Price et al. 1991; Bretz et al. 2002). Over 3 years of field observations, we have determined that PSTs produced by $A$. catenella are acquired by at least three species of planktivorous fish and two species of rock crab in Monterey Bay. These results confirm that PSTs are in fact present in pelagic food webs and that nearshore-benthic predators are capable of becoming contaminated. Since A. catenella can be found in the Bay throughout the year (Table 1), there is potential for these organisms to accumulate PSTs at any time. However, it is most likely to occur during the summer when peak cell densities are observed (Fig. 2), an observation consistent with the historical records of PSTs in sentinel shellfish (Sommer and Meyer 1937; Price et al. 1991).

Although the concentrations of PSTs in the viscera of planktivorous fish samples were typically low, their frequent presence $(56 \%$ of total samples, $n=45)$ clearly shows that exposure to and uptake of PSTs is common in Monterey Bay when A. catenella is present. In all instances of positive fish samples, PSTs were also present in sentinel mussels (Fig. 3), suggesting that nearshore mussels may be an adequate indicator of PST presence in fish, even though they are able to forage further offshore. Based on our observations of $A$. catenella, a probable explanation is that high cell densities occur more frequently and tend to first peak nearshore at SCW, as compared to our offshore site (Fig. 2). As a result, mussels collected nearshore would tend to acquire PSTs at the onset of an A. catenella toxin event in Monterey Bay, and prior to offshore fish populations.

Currently, there are no regulatory mandates in California for PSTs in fish, nor is there any evidence of PSP related fish kills. Interestingly, a similar productive upwelling system in South Africa (the Benguela Current) has experienced sardine ( $S$. sagax) mortalities related to A. catenella, and the safety limit for fish harvesting used there is $80 \mu \mathrm{g}$ STXeq $100 \mathrm{~g}^{-1}$ of viscera (Pitcher and Calder 2000). In at least one mortality event in that region, sardine stomach contents contained between 60,000 and 80,000 A. catenella cells and toxin levels just exceeded the harvestable limit, leading the authors to conclude that these fish are highly sensitive to PSTs (Pitcher and Calder 2000). In this study, we detected PSTs over $80 \mu \mathrm{g}$ STXeq $100 \mathrm{~g}^{-1}$ only once in sardines $\left(250 \mu \mathrm{g}\right.$ STXeq $\left.100 \mathrm{~g}^{-1}\right)$. One critical difference between the two regions is that the density of $A$. catenella reportedly reaches up to 150,000 cells $\mathrm{L}^{-1}$ in South Africa 
(Pitcher and Calder 2000), 1-2 orders of magnitude higher than maximum values typically present on the California coast. Despite this contrast in maximum cell densities, it is still possible for a large number of A. catenella to be ingested by sardines in Monterey Bay. Using reported filter-feeding clearance rates for $S$. sagax feeding on phytoplankton (low estimate $0.28 \mathrm{~L} \mathrm{fish}^{-1} \mathrm{~min}^{-1}$; van der Lingen 1994), we calculated that, at densities of 1,000 cells $\mathrm{L}^{-1}$, 60,000 A. catenella could potentially be consumed in as little as $3.6 \mathrm{~h}$. Since these are modest estimates of feeding rates and cell densities, this would suggest that Monterey Bay sardines could easily ingest the number of cells that were associated with fish kills in South Africa when $A$. catenella are present. Moreover, the mere presence of PSTs in sardines and anchovies demonstrates that these toxins are moving through local food webs in a similar fashion to that found in other regions in which PSP events have affected fish.

Sardines and anchovies are both omnivorous fish capable of feeding directly on phytoplankton or zooplankton and, though they have similar diets, there are subtle differences in their feeding behaviors that may result in the differential accumulation of algal toxins. Lefebvre et al. (2002b) observed a significant difference in the uptake of DA between sardines and anchovies, with anchovies being the more potent of the two vectors. In the present study, the opposite was true and the concentration of PSTs in sardines was always higher than that in anchovies, though the differences were small in all but one case (Table 3 ). Unfortunately, our small sample size limits our conclusions, and so it is not yet apparent if a similar trend would occur with PSTs preferentially accumulating in one species. However, we propose a hypothesis that may explain the apparent contradiction. That is, that toxin accumulation in sardines and anchovies will depend on (1) toxin levels in different plankton size fractions and (2) sardine and anchovy feeding behavior. An interesting pattern observed by van der Lingen (2002), and suggested to be consistent across upwelling regions, is that sardines tend to feed on smaller organisms closer to the base of the food web as compared to anchovies. If feeding directly on the phytoplankton indicates a higher likelihood of acquiring algal toxins, as suggested by Lefebvre et al. (2002b) for anchovies during diatom blooms, then sardines, rather than anchovies, are more likely to acquire toxins in general. Though, that matter is further complicated by the high variability in plankton size and composition in nature, which also affects feeding behavior and clearance rates in these fishes (Koslow 1981; van der Lingen 2002; van der Lingen et al. 2006; Garrido et al. 2007). Thorough investigations by Doucette et al. (2005) on PST levels in different plankton size fractions shows that any of the five plankton size classes they tested could act as an initial vector introducing toxin into the food web. Therefore, the size fraction that contains the greatest toxin levels will dictate which of the two species will ingest more toxins. For example, if the size fraction containing small zooplankton (e.g. $<500 \mu \mathrm{m}$ ) contains the highest toxin concentrations, then we would predict sardines would acquire more toxin than anchovies, as the former demonstrate higher clearance rates at this prey size $(<580 \mu \mathrm{m}$; van der Lingen et al. 2006). Furthermore, van der Lingen et al. (2006) make a compelling argument that physical conditions (e.g. cold mixed vs. warm stable water column) lead to predictable planktonic communities (e.g. large diatoms vs. small flagellates) that favor either anchovies or sardines, respectively; this may provide an explanation as to why anchovies are the dominant vector of the diatom-produced toxin DA (Lefebvre et al. 2002b), whereas sardines appear to uptake more dinoflagellate-produced PSTs. Needless to say, several factors will contribute to the differential accumulation of PSTs in these fish.

During the year we investigated flatfish, we did not detect significant levels of PSTs in any of the samples. In general, 2003 was a year of only moderate A. catenella densities and low PSP activity in shellfish, and it is likely that if this trophic level were affected at all, it would occur during a large-scale PSP event. There is at least one report in which Alexandrium was implicated in a flatfish mortality event in Norway (Tangen et al. (1992) in Lansberg (2002)) and since flatfish are known to accumulate DA in Monterey Bay (Lefebvre et al. 2002a; Vigilant and Silver 2007) it is possible that PSTs may also be present in these fish at times. Vigilant and Silver (2007) propose hypothetical benthic and pelagic pathways that could result in the presence of DA in flatfish; the same or similar pathways could also lead to PST uptake. Benthopelagic-feeding fish, i.e. bottom dwellers that feed in the pelagic zone, could directly obtain PSTs by feeding on pelagic vectors like planktivorous fish or zooplankton (White 1980; Turner et al. 2000; Doucette et al. 2005; this study). Benthic-feeding flatfish could acquire PSTs in two ways, either by indirectly ingesting sediment containing flocculated $A$. catenella cells, resting cysts or PST-contaminated fecal pellets, or alternatively, by the direct consumption of PST-contaminated benthic invertebrates (see Fig. 2 in Vigilant and Silver (2007) for a detailed diagram). While we currently don't know whether local benthic invertebrates other than sand crabs (Sommer 1932; Bretz et al. 2002) and rock crabs (this study) contain PSTs, many benthic organisms do prey directly on bivalves and thus may become toxic by this route. A further investigation of flatfish during a large-scale PSP event is necessary to determine whether PSTs are reaching this trophic level in California.

From September 2004 to August 2005, we tested for the presence of PSTs in brown and red rock crabs caught at SCW. As with planktivorous fish, PSTs were routinely 
detected in the hepatopancreas of rock crabs $(69 \%$ of total samples, $n=29$ ), but at relatively low concentrations, $<50 \mu \mathrm{g}$ STXeq $100 \mathrm{~g}^{-1}$ (Fig. 4). In Washington, JonasDavies and Liston (1985) report PSTs produced by A. catenella (formerly Gonyaulax catenella) in both the viscera, $285 \mu \mathrm{g}$ STXeq $100 \mathrm{~g}^{-1}$, and muscle tissue, $27 \mu \mathrm{g}$ STXeq $100 \mathrm{~g}^{-1}$, of red rock crabs (C. productus). While we did not detect levels this high in the hepatopancreas, this demonstrates that red rock crabs can accumulate dangerous levels of toxin. Both crab species are carnivorous predators and scavengers that feed on a variety of invertebrates (Carroll and Winn 1989), including shellfish, which are thought to be the primary vectors of algal toxins to scavenging crustaceans (Shumway 1995; Torgersen et al. 2005; Sephton et al. 2007). Because PSTs were usually present in sentinel mussels the same week as, or just preceding, the weeks our rock crab samples contained toxin, we speculate that contaminated bivalves are the most likely vectors of PSTs to the crabs collected in this study. There were instances, however, when sentinel mussels were negative and we did detect PSTs in rock crabs (Fig. 4). In most of those samples, the concentrations measured by receptor-binding assay in the crabs were either very low $(<15 \mu \mathrm{g}$ STXeq $100 \mathrm{~g}^{-1}$, well below the detection level of the mouse bioassay) or occurred shortly after the mussel toxin levels had fallen below the detection limit. Furthermore, the elimination of PSTs from the hepatopancreas in other species of crabs and lobsters is thought to occur slowly, taking a period of weeks to months to fully eliminate the toxins (Haya et al. 1994; Desbiens and Cembella 1997; Oikawa et al. 2005; Jester et al. 2008b). The retention of PSTs by rock crabs, if similar to other benthic crustacean species, may also explain why toxins are still present after sentinel mussels have fallen below the detection limit.

While brown and red rock crabs make a small contribution to both a commercial and recreational fishery in California (Carroll and Winn 1989), the presence of PSTs in these crabs suggests that the toxins may also be present in other commercially valuable species, e.g. Dungeness crab (Cancer magister). Along the North American west coast, Dungeness crabs do acquire PSTs (Washington Dept. Soc. Health Services 1980 in Shumway 1995) and the Alaska Division of Environmental Health has set a harvestable limit at $70 \mu \mathrm{g}$ STXeq $100 \mathrm{~g}^{-1}$ in the viscera-lower than the FDA limit used for shellfish, to allow a buffer for response time (Alaska Department of Environmental Conservation 2007). Monterey Bay represents the southernmost range of the $\$ 45$ million Dungeness crab fishery in California, and the general presence of PSTs in Cancer spp., as tested in this study, suggests PSTs may potentially reach Dungeness crab in this region as well.

A comparison of the two species of rock crab collected on the same date implies that brown rock crabs acquire
PSTs more often than red rock crabs. Because of the small sample size, this observation cannot be statistically validated, however, there does not appear to be any significant difference in feeding behavior between brown and red rock crabs (Carroll and Winn 1989), and studies on the diet of these two species are minimal. Highly variable feeding behavior has been noted among individuals of the same species in laboratory feeding trials involving crabs (Oikawa et al. 2005; Jester et al. 2008b), and this variability would thus demand larger sample sizes than those available to us to demonstrate species differences.

Our findings show that PSTs are present in Monterey Bay food webs to a greater degree than previously known and may indicate that other parts of the coast are similarly affected, especially regions thought to be PSP "hot spots" (e.g. Marin County; Price et al. 1991; G. Langlois, personal communication). The California coast is host to a diversity of wildlife and important commercial fisheries, and elevated levels of PSTs could have serious ecological and economic consequences. With regard to human health concerns, the PST levels we found in finfish and rock crabs were typically low in the viscera and, therefore, not likely to be in muscle tissue, the most commonly consumed part of these animals. Individuals that would be at the greatest risk are recreational or subsistence fishers, among those are certain ethnic groups that often consume the entire organism, including the viscera (Fire and Silver 2005). Although there have yet to be any large-scale PSP events involving animal mortalities or human illnesses related to fish or crustaceans in California, the occurrence of significant fish kills, marine mammal deaths and PST-contaminated crustaceans along the coasts of eastern North America and western Africa demonstrate that PST vectoring by organisms other than shellfish is a valid concern (White 1977, 1980; Geraci et al. 1989; Reyero et al. 1999; Pitcher and Calder 2000; Sephton et al. 2007). In California, sardines and anchovies are an important prey item for a variety of marine organisms, including sea lions, whales and sea birds; given the efficiency with which these fish vector DA, it is probable that their predators are at times exposed to PSTs (Work et al. 1993; Lefebvre et al. 1999; Scholin et al. 2000). Among the common predators of rock crabs that may be exposed to PSTs via trophic transfer are benthic fishes, cephalopods, bottom-foraging sharks and sea otters, the last of which certain individuals have been noted to specifically target Cancer spp. (Carroll and Winn 1989; Estes et al. 2003).

The occurrence of PSP-related animal mortality events in other regions with similar levels and frequency of shellfish toxicity events presents a conundrum as to why animal intoxication or deaths have not been observed in California. As PSP events are typically rare and/or sporadic in nature, it is possible that such an occasion may have been missed. 
It is more likely though, that a large-scale mortality event has simply yet to occur along the California coast. The results reported here, however, may allow predictions about potential routes of toxin transfer to higher trophic levels in a region that routinely experiences the presence of $A$. catenella and frequent PST toxicity in shellfish.

Acknowledgments We would like to thank the individuals who assisted in sample collection, especially Kurt Buck, Josh Plant, Capt. Lee Bradford, Chris Reeves, Don Pearson, Itchung Cheung, Veronica Vigilant and the crew of the $R / V P t$. Lobos. Special thanks are due to Gregg Langlois of CDPH for information on local HAB conditions and to Vera Trainer for access to lab space and helpful discussions. This material is based on work supported under a National Science Foundation Graduate Research Fellowship and was funded by NOAA Center for Integrated Marine Technology (CIMT) project (NOAA Award \#NA16OC2936-3) and a University of California Office of the President Award to M. Silver (03T-CEQI-07-0062). Additional funding was awarded to R. Jester by the Friends of Long Marine Lab, the PADI Foundation and the Meyers Oceanographic and Marine Biology Trust Award.

Open Access This article is distributed under the terms of the Creative Commons Attribution Noncommercial License which permits any noncommercial use, distribution, and reproduction in any medium, provided the original author(s) and source are credited.

\section{References}

Alaska Department of Environmental Conservation (2007) Seafood processing and inspection 18 AAC 34.122 seafood product standards. Alaska Administrative Code 23 Apr 2008. <http://oldwww.legis.state.ak.us>

AOAC (2000) AOAC official method 959.08. Paralytic shellfish poison biological method. In: Horwitz W (ed) Official methods of analysis of AOAC international. AOAC, Gaithersburg

Balech E (1995) The genus Alexandrium Halim (Dinoflagellata). Sherkin Island Marine Station, Sherkin Island

Bargu S, Powell CL, Coale SL, Busman M, Doucette GJ, Silver MW (2002) Krill: a potential vector for domoic acid in marine food webs. Mar Ecol Prog Ser 237:209-216. doi:10.3354/meps237209

Bargu S, Powell CL, Wang Z, Doucette GJ, Silver MW (2008) Note on the occurrence of Pseudo-nitzschia australis and domoic acid in squid from Monterey Bay, CA (USA). Harmful Algae 7:45-51. doi:10.1016/j.hal.2007.05.008

Bretz CK, Manouki TJ, Kvitek RG (2002) Emerita analoga (Stimpson) as an indicator species for paralytic shellfish poisoning toxicity along the California coast. Toxicon 40:1189-1196. doi:10.1016/S0041-0101(02)00127-7

California Department of Fish and Game Marine Region (2007) Final California commercial landings for 2006. Los Alamitos, California

Carroll JC, Winn RN (1989) Species profiles: life histories and environmental requirements of coastal fishes and invertebrates (Pacific Southwest)—brown rock crab, red rock crab, and yellow crab. US Fish Wildl Serv Biol Rep 82 (11.117). US Army Corps of Engineers, TR EL-82-4

Desbiens M, Cembella AD (1997) Retention and possible transformation of paralytic shellfish toxins in lobster (Homarus americanus). Bull Aquacult Assoc Can 97(2):75-77

Doucette GJ, Turner JT, Powell CL, Keafer BA, Anderson DM (2005) Trophic accumulation of PSP toxins in zooplankton during
Alexandrium fundyense blooms in Casco Bay, Gulf of Maine, April-June 1998. I. Toxin levels in A. fundyense and zooplankton size fractions. Deep Sea Res Part II Top Stud Oceanogr 52:27642783. doi:10.1016/j.dsr2.2005.06.031

Durbin E, Teegarden G, Campbell R, Cembella A, Baumgartner MF, Mated BR (2002) North Atlantic right whales, Eubalaena glacialis, exposed to paralytic shellfish poisoning (PSP) toxins via a zooplankton vector, Calanus finmarchicus. Harmful Algae 1:243251. doi:10.1016/S1568-9883(02)00046-X

Estes JA, Riedman ML, Staedler MM, Tinker MT, Lyon BE (2003) Individual variation in prey selection by sea otters: patterns, causes and implications. J Anim Ecol 72:144-155. doi:10.1046/ j.1365-2656.2003.00690.x

Fire SE, Silver MW (2005) Domoic acid in the Santa Cruz wharf fishery. Calif Fish Game 91:179-192

Fritz L, Quilliam M, Wright J, Beale A, Work T (1992) An outbreak of domoic acid poisoning attributed to the pennate diatom Pseudonitzschia australis. J Phycol 28:439-442. doi:10.1111/j.00223646.1992.00439.x

Garrido S, Marcalo A, Zwolinski J, van der Lingen CD (2007) Laboratory investigations on the effect of prey size and concentration on the feeding behaviour of Sardina pilchardus. Mar Ecol Prog Ser 330:189-199. doi:10.3354/meps330189

Geraci JR, Anderson DM, Timperi RJ, St. Aubin DJ, Early GA, Prescott JH, Mayo C (1989) Humpback whales (Megaptera novaeangliae) fatally poisoned by dinoflagellate toxin. Can J Fish Aquat Sci 46:1895-1898. doi:10.1139/f89-238

Goldberg J (2003) Domoic acid in the benthic foodweb of Monterey Bay, California. Marine Science MS Thesis, California State University of Monterey Bay, Moss Landing, California

Halstead BW, Schantz EJ (1984) Paralytic shellfish poisoning. WHO Offset Publ, vol 76. World Health Organization, Geneva, pp 1-60

Haya K, Oshima Y, Young-Lai WW (1994) Profile of paralytic shellfish poisoning toxins in lobsters during uptake and depuration. In: Forbes JR (ed) Proceedings of the 4th Canadian workshop on harmful marine algae. Can Tech Rep Fish Aquat Sci 2016, p 17

Horner RA, Garrison DL, Plumley FG (1997) Harmful algal blooms and red tide problems on the U.S. west coast. Limnol Oceanogr 42:1076-1088

Hortsman DA (1981) Reported red-water outbreaks and their effects on fauna of the west and south coasts of South Africa, 1959-1980. Fish Bull S Afr 15:71-88

Jester RJ, Silver M, Langlois G, Vigilant V, Lefebvre KA, Baugh KA (2008a) A shift in the dominant toxin-producing algal species in central California alters phycotoxins in food webs. Harmful Algae. doi:10.1016/j.hal.2008.07.001

Jester RJ, Rhodes L, Beuzenberg V (2008b) Uptake of paralytic shellfish poisoning and spirolide toxins by paddle crabs (Ovalipes catharus) via a bivalve vector. Harmful Algae. doi:10.1016/ j.hal.2008.08.002

Jonas-Davies J, Liston J (1985) The occurrence of PSP toxins in intertidal organisms. In: Anderson DM, White AW, Baden DG (eds) Toxic dinoflagellates. Elsevier, New York, pp 467-472

Kao CY (1993) Paralytic shellfish poisoning. In: Falconer IR (ed) Algal toxins in seafood and drinking water. Academic Press, London, pp 75-86

Koslow J (1981) Feeding selectivity of schools of northern anchovy, Engraulis mordax, in the southern California bight. Fish Bull (Wash D C) 79:131-142

Langlois GW, Kizer KW, Hansgen KH, Howell R, Loscutoff SM (1993) A note on domoic acid in California coastal mollusks and crabs. J Shellfish Res 12:467-468

Lansberg JH (2002) The effects of harmful algal blooms on aquatic organisms. Rev Fish Sci 10:113-390. doi:10.1080/20026491 051695 
Lefebvre KA, Powell CL, Busman M, Doucette GJ, Moeller PDR, Silver JB, Miller PE, Hughes MP, Singaram S, Silver MW, Tjeerdema RS (1999) Detection of domoic acid in northern anchovies and California sea lions associated with an unusual mortality event. Nat Toxins 7:85-92. doi:10.1002/(SICI)15227189(199905/06)7:3<85::AID-NT39>3.0.CO;2-Q

Lefebvre KA, Bargu S, Kieckhefer T, Silver MW (2002a) From sanddabs to blue whales: the pervasiveness of domoic acid. Toxicon 40:971-977. doi:10.1016/S0041-0101(02)00093-4

Lefebvre KA, Silver MW, Coale SL, Tjeerdema RS (2002b) Domoic acid in planktivorous fish in relation to toxic Pseudo-nitzschia cell densities. Mar Biol (Berl) 140:625-631. doi:10.1007/s00227-001-0713-5

MacLean JL (1979) Indo-Pacific red tides. In: Taylor DL, Seliger HH (eds) Toxic dinoflagellate blooms. Proceedings of the 2nd international conference on toxic dinoflagellate blooms. Elsevier, North Holland, pp 173-178

McKernan DL, Scheffer VB (1942) Unusual numbers of dead birds on the Washington coast. Condor 44:264-266. doi:10.2307/1364402

Meyer KF, Sommer H, Schoenholz P (1928) Mussel poisoning. Am J Prev Med 2:365-394

Mianzan HW, Pajaro M, Machinandiarena L, Cremonte F (1997) Salps: possible vectors of toxic dinoflagellates? Fish Res 29:193-197. doi:10.1016/S0165-7836(96)00526-7

Miller PE, Scholin CA (1998) Identification and enumeration of cultured and wild Pseudo-nitzschia (Bacillariophyceae) using species-specific LSU rRNA-targeted fluorescent probes and filter-based whole cell hybridization. J Phycol 34:371-382. doi:10.1046/j.1529-8817.1998.340371.x

Miller PE, Scholin CA (2000) On detection of Pseudo-nitzschia species using rRNA-targeted probes: sample fixation and stability. J Phycol 36:238-250. doi:10.1046/j.1529-8817.2000.99041.x

Montoya NG, Akselman R, Franco J, Carreto JI (1996) Paralytic shellfish toxins and mackerel (Scomber japonicus) mortality in the Argentine sea. In: Yasumoto T, Oshima Y, Fukuyo Y (eds) Harmful and toxic algal blooms. IOC UNESCO, Paris, pp 417-420

Oikawa H, Fujita T, Satomi M, Suzuki T, Kotani Y, Yano Y (2002) Accumulation of paralytic shellfish poisoning toxins in the edible shore crab Telmessus acutidens. Toxicon 40:1593-1599. doi:10.1016/S0041-0101(02)00176-9

Oikawa H, Satomi M, Watabe S, Yano Y (2005) Accumulation and depuration rates of paralytic shellfish poisoning toxins in the shore crab Telmessus acutidens by feeding toxic mussels under laboratory controlled conditions. Toxicon 45:163-169. doi:10.1016/j.toxicon.2004.10.004

Oikawa H, Fujita T, Saito K, Satomi M, Yano Y (2007) Difference in the level of paralytic shellfish poisoning toxin accumulation between the crabs Telmessus acutidens and Charybdis japonica collected in Onahama, Fukushima Prefecture. Fish Sci 73:395-403. doi:10.1111/j.1444-2906.2007.01347.x

Oshima Y, Kotaki Y, Harada T, Yasumoto T (1984) Paralytic shellfish toxins in tropical waters. In: Ragelis EP (ed) Seafood toxins. ACS symposium series 262, American Chemical Society, Washington DC, pp 161-170

Pitcher GC, Calder D (2000) Harmful algal blooms of the southern Benguela Current: a review and appraisal of monitoring from 1989 to 1997. S Afr J Mar Sci 22:255-271

Price DW, Kizer KW, Hansgen KH (1991) California's paralytic shellfish poisoning prevention program, 1927-89. J Shellfish Res 10:119-145

Reyero M, Cacho E, Martinez A, Vazquez Js, Marina A, Fraga S, Franco JM (1999) Evidence of saxitoxin derivatives as causitive agents in the 1997 mass mortality of monk seals in the Cape Blanc peninsula. Nat Toxins 7:311-315. doi:10.1002/1522-7189 (199911/12)7:6<311::AID-NT75>3.0.CO;2-I

Scholin CA (1994) Identification of group- and strain-specific genetic markers for globally distributed Alexandrium (Dinophyceae). II.
Sequence analysis of a fragment of the LSU rRNA gene. J Phycol 30:999-1011. doi:10.1111/j.0022-3646.1994.00999.x

Scholin CA, Villac MC, Buck KR, Krupp JM, Powers DA, Fryxell GA, Chavez FP (1994) Ribosomal DNA sequences discriminate among toxic and non-toxic Pseudonitzschia species. Nat Toxins 2:152-165. doi:10.1002/nt.2620020403

Scholin CA, Gulland F, Doucette GJ, Benson S, Busman M, Chavez FP, Cordaro J, De Long R, De Vogelaere A, Harvey J, Haulena M, Lefebvre K, Lipscomb T, Loscutoff S, Lowenstine LJ, Marin R, Miller PE, McLellan WA, Moeller PDR, Powell CL, Rowles T, Silvagni P, Silver M, Spraker T, Trainer V, Van Dolah FM (2000) Mortality of sea lions along the central California coast linked to a toxic diatom bloom. Nature 403:80-84. doi:10.1038/47481

Sephton DH, Haya K, Martin JL, Le Gresley MM, Page FH (2007) Paralytic shellfish toxins in zooplankton, mussels, lobsters and caged Atlantic salmon, Salmo salar, during a bloom of Alexandrium fundyense off Grand Manan Island, in the Bay of Fundy. Harmful Algae 6:745-758. doi:10.1016/j.hal.2007.03.002

Shumway SE (1995) Phycotoxin-related shellfish poisoning: bivalve molluscs are not the only vectors. Rev Fish Sci 3:1-31

Sommer H (1932) The occurrence of the paralytic shellfish poison in the common sand crab. Science 76:574-575. doi:10.1126/science. 76.1981 .574

Sommer H, Meyer KF (1937) Paralytic shellfish poisoning. Arch Pathol (Chic) 24:560-598

Teegarden G, Cembella A (1996) Grazing of toxic dinoflagellates, Alexandrium spp., by adult copepods of coastal Maine: implications for the fate of paralytic shellfish toxins in marine food webs. J Exp Mar Biol Ecol 196:145-176. doi:10.1016/0022-0981(95)00128-X

Torgersen T, Aasen J, Aune T (2005) Diarrhetic shellfish poisoning by okadaic acid esters from Brown crabs (Cancer pagurus) in Norway. Toxicon 46:572-578. doi:10.1016/j.toxicon.2005.06.024

Trainer VL, Poli MA (2000) Assays for dinoflagellate toxins, specifically brevetoxin, ciguatoxin, and saxitoxin. In: Rochat $\mathrm{H}$, Martin-Eauclaire MF (eds) Methods and tools in biosciences and medicine. Birkhauser, Basel, pp 1-19

Turner JT, Doucette GJ, Powell CL, Kulis DM, Keafer BA, Anderson DM (2000) Accumulation of red tide toxins in larger size fractions of zooplankton assemblages from Massachusetts Bay, USA. Mar Ecol Prog Ser 203:95-107. doi:10.3354/meps 203095

van der Lingen CD (1994) Effect of particle-size and concentration on the feeding-behavior of adult pilchard Sardinops sagax. Mar Ecol Prog Ser 109:1-13. doi:10.3354/meps109001

van der Lingen CD (2002) Diet of sardine Sardinops sagax in the southern Benguela upwelling ecosystem. S Afr J Mar Sci 24:301-316

van der Lingen CD, Hutchings L, Field JG (2006) Comparative trophodynamics of anchovy Engraulis encrasicolus and sardine Sardinops sagax in the southern Benguela: are species alternations between small pelagic fish trophodynamically mediated? Afr J Mar Sci 28:465-477

Vigilant V, Silver M (2007) Domoic acid in benthic flatfish on the continental shelf of Monterey Bay, California, USA. Mar Biol (Berl) 151:2053-2062. doi:10.1007/s00227-007-0634-z

Wekell JC, Hurst J, Lefebvre KA (2004) The origin of the regulatory limits for PSP and ASP toxins in shellfish. J Shellfish Res 23:927-930

White AW (1977) Dinoflagellate toxins as probable cause of an Atlantic herring (Clupea harengus harengus) kill, and pteropods as apparent vector. J Fish Res Board Can 34:2421-2424

White AW (1980) Recurrence of kills of Atlantic herring (Clupea harengus harengus) caused by dinoflagellate toxins transferred through herbivorous zooplankton. Can J Fish Aquat Sci 37:22622265. doi:10.1139/f80-083

Work TM, Barr B, Beale AM, Fritz L, Quilliam MA, Wright JLC (1993) Epidemiology of domoic acid poisoning in brown pelicans (Pelecanus Occidentalis) and brandt cormorants (Phalacrocorax Penicillatus) in California. J Zoo Wildl Med 24:54-62 